\title{
Leather Waste Management Scenario in Developed and Developing Nations
}

\author{
K. Koppiahraj, S. Bathrinath, S. Saravanasankar
}

\begin{abstract}
Solid waste management has been a serious issue of concern for both developing and developed nations as it stands out to be a potential threat in term of health hazards, environmental exploitation and economic burden. Hence, a properly well-designed eco-friendly solid waste management system is mandatory. Most of the developed countries had witnessed success in handling solid waste generated by households and industries by implementing closed-loop supply chain management (CLSCM) and majorly by outsourcing. But, solid waste management scenario in developing nations is entirely different and is not even in initial stage. This paper specially emphasize on leather industries solid waste management as leather industries around the world possess threat to mankind and environment. In this study, papers on leather solid waste management is selected and reviewed. Finally, a strategic comparison is made between the waste management techniques followed in developing and developed nation.
\end{abstract}

Keywords: Closed-loop supply chain management, Leather industries, Outsourcing, Solid waste management.

\section{INTRODUCTION}

$\mathrm{P}$ to be provided by the municipality to ensure better environmental condition. Poor management of solid wastes may pave way for environmental degradation and bring in health hazards. The solid waste management scenario is different in developed and developing nations. Most of the developed nations are adopting advanced and properly planned solid waste management techniques whereas in developing nations outdated and inefficient techniques are followed. The importance and awareness of proper solid waste management is not even in initial stage in developing nations. Many developing nation witnessed an alarming increase in the quantity of solid wastes as a result of rapid urbanization and economic growth. Statistical report warns that the solid waste generation rate is spontaneous than the urbanization rate. By the year 2025, it was estimated that $1.42 \mathrm{~kg}$ of solid waste will be generated by an individual person per day. Improper solid waste management techniques like open dumping and incineration results in

Revised Manuscript Received on December 5, 2019

* Correspondence Author

K.Koppiahraj, Department of mechancical engineering, Kalasalingam Academy of research and education, Krishnankoil-626126, India. Email: koppiahraj1993@gmail.com

S.Bathrinath*, Department of mechancical engineering, Kalasalingam Academy of research and education, Krishnankoil-626126, India. Email: bathri@gmail.com

S.Saravanasankar, Department of mechancical engineering, Kalasalingam Academy of research and education, Krishnankoil-626126, India. Email: ssaravanasankar@klu.ac.in serious respiratory health problems [1]. Poor solid waste management will lead to serious environmental problems like acidification, global warming, eutrophication and human toxicity. Study carried in three cities namely Panchkula, Mohali and Chandigarh, regarding waste management suggests recycling, composting and sanitary landfill as the available way to handle solid waste [2]. Waste management problem in a country is the result of technological, financial and political failure. Proper consideration of technical, economic and social information is necessary in achieving sustainable waste management [3]. In most waste management cases, the effectiveness and usefulness of the proposed waste management technique is analyzed using Life Cycle Assessment (LCA) process. Procurement, production, use and disposal are the four phases of a product's life cycle. Iron and steel industries, plastic industries, rubber production, textile manufacturing and leather production are the major industries releasing solid wastes into the environment [4]. Leather manufacturing industry is a traditional and major employment providing sector, which is present all over the world. Initially human nomad used the hunted animal's skin to protect them against the prevailing heat, cold and rain. As a result of human evolution, shoes, belts, jackets, handbags, saddles, furniture and bags are manufactured from leather. For manufacturing the above mentioned products, the animal skin has to be flexible and durable. To obtain the above mentioned properties, the animal skin is subjected to series of chemical treatments called tanning process. Raw skin and hides of cattle, horse, elephant, crocodile and polar bears are subjected to tanning process and the end product obtained is leather. As a result of free trade, the leather exports gained great leap and considerably contributed to the nation's economy [5]. It was found that more than $60 \%$ of leathers are used in footwear manufacturing.

According to a global study, china (17.4\%) is the leading leather exporter followed by Italy (14.8\%), Vietnam (11.6\%) and Germany (6.3\%). In total global leather export, India's share is $2.7 \%$ which is equal to 1.4 billion US dollars. Countries such as US, Germany and other EU countries are the largest importers of leather products. Even though Leather industries immensely contribute to developing nation's economy, it makes adverse impact on the environment. Leather products have to undergo series of chemical reactions and at each stage some amount of wastes is released [6]. Various operations involved in Leather processing are shown in Fig. 1 [7]. Stringent environmental regulations and demand for eco-friendly manufacturing strategies forced leather industries to implement sustainable manufacturing. Adopting an Eco-friendly manufacturing design will help a firm in reducing ecological footprint. Conventional 3R (Reduce,

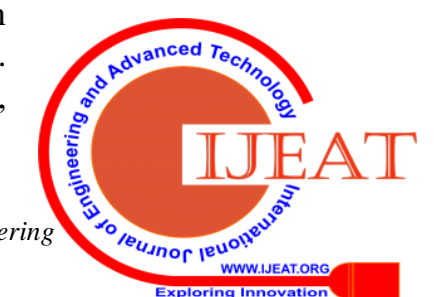


Reuse and Recycle) strategy replaced by 6R (Reduce, Reuse, Recover, Redesign, Remanufacture, Recycle) strategy forms the base for sustainable manufacturing and Closed-Loop supply chain management. A case study [8] carried in a fashion industry using eco-design and recycling indicates that most of the leather waste from the post-consumed products can be converted into useful products. Generation of enormous amount of leather waste is the result of volatility in consumer market as it is unsustainable. However, implementation of an environment friendly production strategy is mandated for all leather processing industries. Progress in implementation of green technology and the responsibility of leather sectors in adhering to environmental regulations are detailed in the following sections.

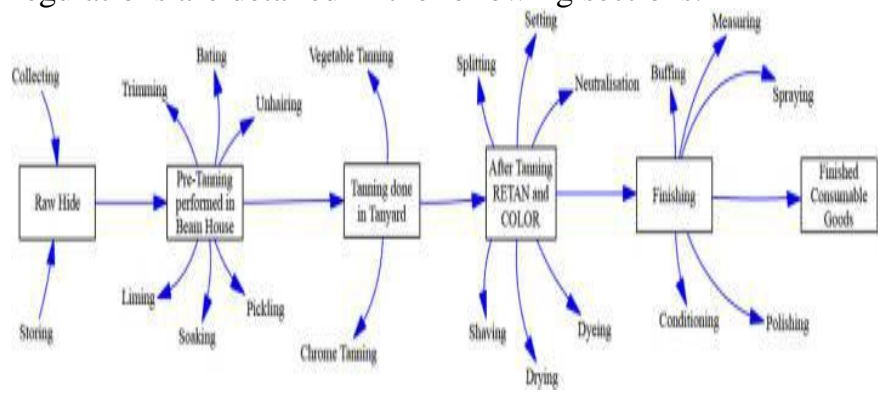

Fig. 1. Various operations in leather processing

\section{ENVIRONMENTAL IMPACT}

Every year, globally 4 million tons of solid wastes are generated by leather industries. Leather products imposes threat from its processing stage to decomposing stage i.e., from cradle to grave. Leather manufacturing process takes place in three stages namely beam house operations, tannery process and finishing process. Among the three stages, the second one, Tanning operation is the vital as well as the troublesome stage. Tanning operation stage is vital because at this stage only the raw skin or hide material is made into durable and resistant leather. At the same time, this stage is a worrying stage as it generates effluents and solid wastes. Conventional vegetable tanning method was replaced by chrome tanning method for increasing the production rate of leather, but the chrome tanning method brought many environmental problems. The wastes released at each stage are harmful to the environment. The untreated water effluents from the tanneries are directly released into the rivers and thus contaminating the water bodies. The major compositions of the effluents are chromium, chlorine, cadmium, nickel, zinc and lead. A study estimates that out of $500 \mathrm{~kg}$ of raw hides, only $75 \mathrm{~kg}$ is converted into leather while the remaining are excluded as wastes. Quantity and types of solid wastes produced by tanneries in processing 1 ton of raw skin and hide is tabulated in Table 1 [9]. The excluded waste from the beam house such as animal hair and flesh could be converted into useful by-products by hydrolysis. But, these excluded wastes from the beam house are dumped in the open space as landfills which give rise to harmful microbes. Decomposition of solid wastes from Leather industries may release methane gas.

The excluded solid wastes from tannery are classified into four types: Tanned Collagen, Untanned Collagen, non-collagenous protein waste, Non-proteinious waste. Some of the excluded wastes can be converted into useful products like biodiesel, fat liquoring oil and are used in grease and activated carbon production [10]. Bio-chemical oxygen demand (BOD), Chemical Oxygen Demand (COD), Total Dissolved Solids (TDS) norms and sludge are the major environmental problems generated by the solid wastes released from leather industries [11]. The characteristics and quantity of tannery sludge generated varies based on the raw materials and tanning technology used. Chromium, the main agent used in leather tanning process is considered as a carcinogen generating hazardous waste [12]. Globally $85 \%$ of raw skins/hides are processed using chrome salts. Being cheap and easy to use are the reasons for using chrome salts. Every year around 6, 00,000 metric tons of solid waste containing chromium is produced by leather industries [13]. Since $60 \mathrm{~m}^{3}$ of water is needed for processing one ton of hide, a large amount of waste water is generated during leather production [14]. These effluents contain unused chemicals, leached proteins, acids, tannins, solvents and degraded products of hide and skins which are hazardous to the environment.

Table- I: Quantity and Types of Solid Wastes Generated from Tanneries for 1 ton of raw skins/Hides

\begin{tabular}{|c|c|}
\hline Types of Solid Wastes & Quantity (Kg) \\
\hline Hair & 100 \\
\hline Dry sludge & 125 \\
\hline Buffing Dust & 65 \\
\hline Fleshing & 120 \\
\hline Chrome Shaving \& splitting & 160 \\
\hline Trimming & 105 \\
\hline Salt & 300 \\
\hline
\end{tabular}

It was found that nearly one third of the water pollution is due to leather industries effluents. Leather dusts, produced during buffing operation contain impregnated chemicals and hair fragments. Most of the Leather industries in developing nations are facing the aforementioned problems and were closed for not following the suggested environmental regulations. In countries like Bangladesh and India, the Leather sector is considered as a reliable source of income and it significantly contributes to the economy of the nation. It generates employment opportunities for skilled/semi-skilled and unskilled laborers [15]. But on the other hand, factors like adoption of outdated/inefficient technology, high cost of capital investment, technical problems and lack of supervising facilities hinders the leather industries progress towards green technology [16] The problem of solid waste management also exists in developed nations but by adopting advanced and potential technology, the developed nations are overcoming the solid waste management problems [17]. But solid wastes generated differ from one country to another country or one region to another region depending on industrial organization, economic condition, life style and waste management system [18]. All the countries are trying to handle solid wastes effectively and Fig. 2. shows the global solid waste management scenario (World Bank report). Pyrolysis, the common technique used in conversion of waste into energy was found to produce large amount of chlorine waste [19]. From World Bank's report, it is evident 
open dumping is commonly practiced in solid waste management and it will prompt health hazard and environmental degradation. Landfill system is identified as the worst waste management practice based on a study carried in Italy and insisted energy recycling is ranked as better waste management system [20].

In a Study carried in Iran regarding solid waste management practice, landfill was identified as the worst practice while combination of anaerobic digestion and incineration was identified as the most ecofriendly practice [21].

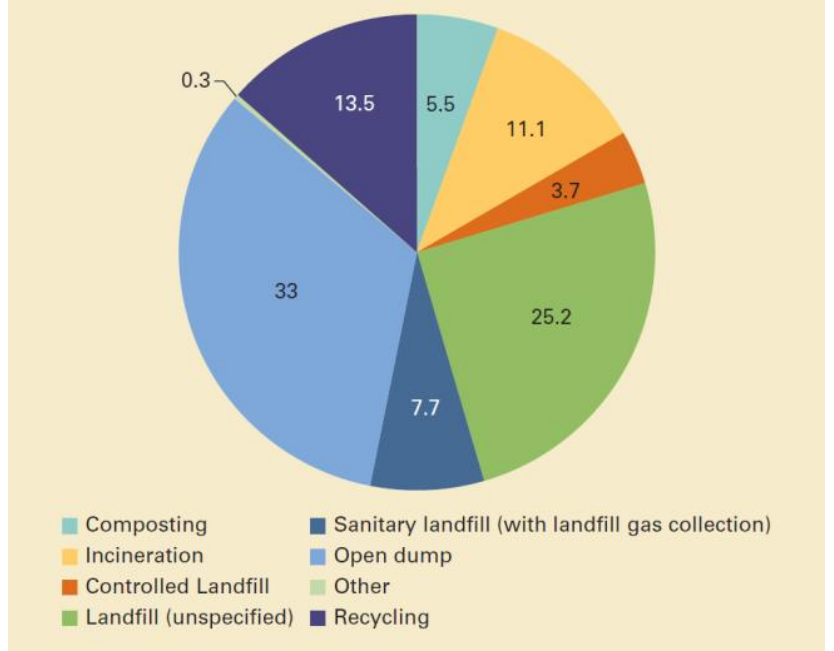

Fig. 2. Global treatment and disposal of waste (percent)

\section{CSR OF LEATHER INDUSTRIES}

Increasing environmental awareness among customers and demand for green products urged the manufacturing sectors to come up with an environment assisted manufacturing technique. Further, stringent environmental regulation and government's industrial protocol mandated corporate social responsibility (CSR) for industries. CSR topic covers areas like social, legal, ethical, financial, environmental and economic dimensions of an organization. Social dimensions include child labor prohibition, employment generation and safety aspects for worker while environmental aspects include accident prevention and mitigation of environmental degradation. Factors like emission reduction, environmental conservation, strategic advancement, risk mitigation and competitive advantage are some drivers in CSR of industries [22]. In short, CSR is defined as an umbrella that describes the multi-faceted bond between society and industry. Contrarily, a study [23] indicates that small medium entrepreneurs (SMEs) are not aware of advantages and necessity of following CSR. By understanding the CSR principle, most of the established manufacturing industries around the world adopted closed-loop supply chain (CLSC), Lean manufacturing, Zero waste manufacturing techniques and reverse logistics technique [24]. There exists a wide gap in information and knowledge sharing between an established organizations and SMEs regarding CSR [25]. Most of the SMEs are criticized for not adhering to the environmental policy and for not paying attention to CSR concept. But SMEs significantly contributes to the economy of developing nations by generating job opportunities and by alleviating poverty. From the studies, it could be understood that there exists a difference in understanding CSR concept between developed and developing countries [26].

The concept of CLSC has been the area of interest for most of the researchers and academicians all over the world and CLSC has undergone more transformation in recent years [27]. In the study [28], examined the success of implementing CLSC in leather footwear industry and the structure of CLSC is found straight opposite to forward supply chain i.e., begins from customer and ends with manufacturers. By consuming 6.9 pair of shoes per person annually, China and USA become world's largest footwear consuming countries. While it was 4.5 in European Union and 5.3 in UK and the scenario is entirely different in developing countries like India (0.6) and Vietnam (0.5). In term of footwear production, China tops the chart with 14,200 million of footwear followed by India (2, 209 million), Brazil (900 million) and Vietnam (770 million). It was identified that only less than $5 \%$ of 20 billion pairs of shoes produced in a year is recycled whereas the remaining goes to incineration or landfill [29]. By understanding the CSR policy, a renowned sports shoe manufacturer Nike introduced a recycling program called 'NikeGo Places'. Through this program, nearly 16 million pairs of damaged and worn-out athletic shoes were recycled [30]. Similarly, in developing nations, organizations like "It's from the sole" and "soles for shoes" are actively accepting donated footwear. For analyzing the effectiveness of the recycled or reused solid wastes, Material Flow Analysis (MFA) was carried along with LCA [31]. From the results, it was identified that among various municipal solid wastes generated, paper and cardboard wastes are recycled in large extent while the remaining wastes are not appreciably recycled. Most of the developing countries are used as a manufacturing site by multinational companies. As a result, the generated industrial waste accumulates into the municipal solid waste and increases the waste management burden. According to a study [32] carried out using waste input output (WIO) analysis in Taiwan, it was found that wastes generated from electrical and leather industries accounts for major proportion of generated industrial waste. In a developing country like India, it was suggested that public-private partnership (PPP) will ensure optimal success in handling solid wastes [33]. The concept of PPP arises as a result when either of the individuals was unable to accomplish the specific tasks. Implementation of PPP will create an opportunity for joint venture where both developed and developing countries will work together in solid waste management. Factors like sociological, managerial and economic aspects should be evaluated while implementing PPP concept. The study also urged the co-ordination of rag-pickers from different parts of a city for in handling the solid wastes effectively.

According to a report, rag-pickers roughly reduced $20 \%$ load on transportation and landfill; saves $14 \%$ of municipal budget annually. The wastes collected by the rag-pickers are segregated into different level for retaining the product value as shown in Fig. 3 [34]. EASEWASTE (Environmental Assessment of Solid Waste Systems and Technologies), a decision support model, was created in Denmark to estimate waste flow, resource consumption

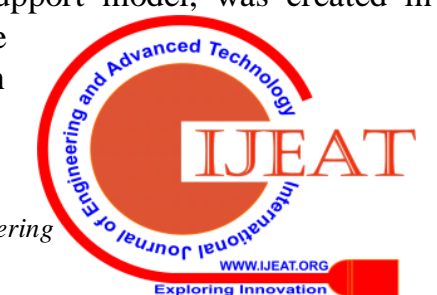


and environmental degradation of waste management systems. The developed model generates an assessment score in terms of global warming, ozone depletion and eco-toxicity [35]. To understand the status of CSR implementation in developing countries, a study carried in Bangladesh identified economic factors, social and environmental factors as the drivers in CSR implementation [36]. Non-compliance in solid waste management is the result of poor training, inefficient planning and financial constraints.

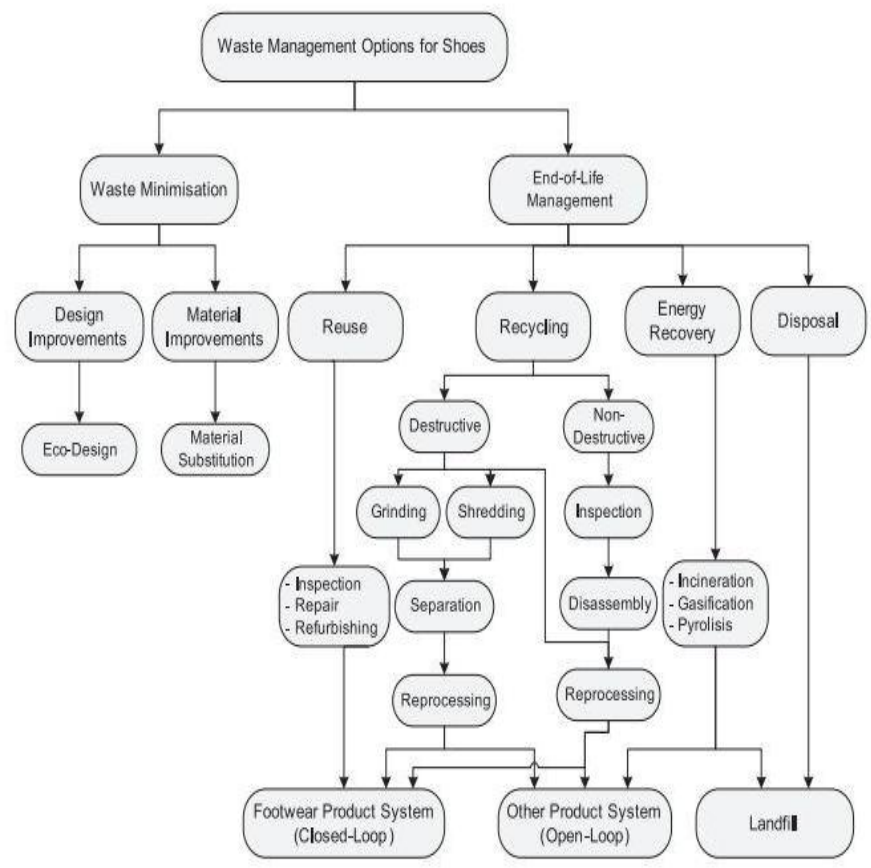

Fig. 3. Segregation of solid wastes

\section{MOVING TOWARDS GREEN TECHNOLOGY}

A typical solid waste management consists of collection, transportation, treatment process and disposal. The waste management system followed in developed countries usually occurs in stage by stage manner. The three main stages of waste management system followed in developed countries towards smart city (SC) project are waste categorization, waste quantification and waste controlling practices [37]. In Waste categorization process, the generated wastes are sorted as organic, plastic, metal scrap and leather wastes. While in waste quantification, the amount of waste generated in various industries like food processing, leather sectors, e-waste, medical waste and construction industries are calculated and in waste management practice, from recycling, reusing and redesigning practice the suitable practice is selected. To overcome the gap in waste management practice, Internet of Thing (IoT) assisted waste management practices are adopted in developed countries. The IoT assisted waste management is a combination of Geographical Information System (GIS) sensor and Global System for Mobile (GSM) communication. With the aid of IoT assisted waste management technology, it is possible to identify the location, quantity and the type of wastes dumped in the garbage bins.

In the progress of moving towards green technology or adopting sustainable techniques, factors such as type and quantity of chemicals used, quantity of waste generated, commitment from management and technology adopted should be analyzed. The general criteria to be considered while selecting a cleaner leather processing are (a) adverse effect by generated waste (b) generated waste manageability (c) ecological value of processed waste (d) costs of post-processed waste (e) maximization of process water. To overcome the negative impact created by leather tanneries, the concept of zero-discharge tanning was created. Though the concept of achieving zero-discharge appears to be a global challenge, it is achievable by adopting the following strategies either alone or in combination: usage of ecofriendly chemicals, optimum utilization of the chemicals, reusing the chemicals recovered and process integration [38]. From Table 1, it could be inferred that trimmings accounts for considerable percentage in solid wastes generated by leather tanneries. In order to bring down the negative impact created by leather industries, various eco-friendly enzymes/catalyst and tanning agents were developed over the years [39]. The trimming waste from tanneries consists of collagen and hairs. Hair removal is a crucial process and usage of inorganic sulfide (a conventional biocatalyst) in hair removing process will have adverse environmental effect. In order to lessen the adverse environmental impact left by inorganic sulfide, an eco-being biocatalyst called Keratinolytic protease was developed [40]. In a similar study [41] related to sulfide reduction during unhairing process, it was identified that the inclusion of hydrogen peroxide during unhairing process reduces the sulfide usage and increases the chromium absorption rate of hides. China, world's largest leather producing country responded to customers demand by developing a dust suppressor using collagen (a discarded waste from leather industries) through sustainable manufacturing technique [42]. The unutilized hairs from the tanneries are roughly used as boiler feed in gelatin manufacturing. Formaldehyde is generally used as a re-tanning agent in leather industries for compaction but it becomes a carcinogen for environmental degradation. Hence, for effective trimming, a re-tanning agent free from formaldehyde was developed by environmental assisted leather processing [43]. Biopol, a biopolymer used as a tanning, re-tanning and fatting agent is obtained by polymerization and esterification process from the hydrolyzed collagen which is discarded as waste from tanneries [44].

Among various wastes eliminated from the leather tanneries, animal fat is an important one. The amount of fat wastes eliminated varies depending upon the type of animal skin used. The fat content of pig or sheep skin is higher than that of cattle skin. The fat content also varies depending upon the geographical and climatic conditions. For instance, the fat content of European skin is $5 \%-10 \%$ whereas the fat content of Australian skin is $20 \%-40 \%$. With the view of reusing or recovering the leather waste, eliminated animal fat from tanneries are used in production of biodiesel [45]. The experimental result of biodiesel prepared by blending animal fat with diesel showed reduction in the emission of $\mathrm{CO}_{2}, \mathrm{CO}$ and $\mathrm{NO}_{\mathrm{x}}$. To come up with a better solution for mitigating environmental wastes generated by manufacturing industries, researchers suggested microbial enzymes as potential solution [46]. Animal fleshing eliminated from leather

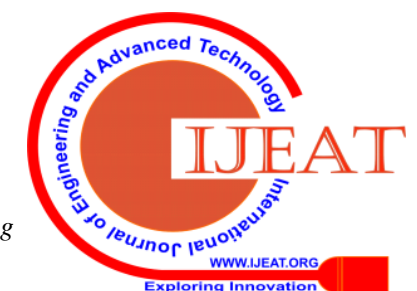


industries is vermicompost using Eisenia foetida and the results identified the vermicomposting as nutrient-enriched product [47]. In order to reduce the effluent load such as COD, BOD and TDS from leather industries, a new enzymatic process for fiber opening using Aspergillus Terreus is developed as a substitute for conventional liming process [48]. The quality of leather obtained by using the proposed enzymatic technique was found to be better than that of conventional liming leather. As an attempt in effective management of tannery sludge, it is used in developing a composite along with rice husk ash and cement [49]. Through various R\&D works, advanced technologies for mitigating leather and tannery pollution were developed, but they are not commercially available in developing countries [50].

\section{CONCLUSION}

With the issuance of strict environmental regulations, it becomes necessary for all manufacturing sectors to adopt ecofriendly manufacturing techniques. The adverse impact left by the leather tanneries on the environment is ineffable. Exploding population, beaming urbanization and rapidly changing lifestyle increases the generation of solid waste. Conventional techniques like incineration and landfilling are followed by most industries in developing countries. With the aid of advanced technology, the developed countries had witnessed solution in tackling the hazards created by solid waste from household and industries. However, the waste management scenario is entirely different in developing nations. From literature reviews, it was identified that the advanced technology followed in developed nations are not available and feasible in developing nations. The reason for non-availability and non-feasibility is the poor understanding of CSR by industries in developing nations. Hence, a better understanding about CSR by industries and implementation of PPP in developing countries will turn out to be a best solution in handling solid wastes.

\section{REFERENCES}

1. P. Shrivastava, S. Mishra and S. K. Katiyar, "A Review of Solid Waste Management Techniques using GIS and Other Technologies," In 2015 International Conference on Computational Intelligence and Communication Networks (CICN), 2015, pp. 1456-1459, IEEE.

2. R. Rana, R. Ganguly and A. K. Gupta, "Life-cycle assessment of municipal solid-waste management strategies in Tricity region of India," Journal of Material Cycles and Waste Management, 2019, 1-18.

3. B. Khoshnevisan, S. Rafiee and M. Tabatabaei, "Waste Management Strategies: Life Cycle Assessment (LCA) Approach,” In Biogas, 2018 pp. 305-331, Springer, Cham.

4. S. K. Doifode, A. G. Matani and A. G. Matani, "Effective industrial waste utilization technologies towards cleaner environment," International Journal of Chemical and Physical Sciences, 4(NCSC), 2015, 536.

5. H. Jiang, J. Liu and W. Han, "The status and developments of leather solid waste treatment: A mini-review,"Waste Management \& Research, 2016, 34(5), 399-408.

6. A. Dwivedi, D. Agrawal and J. Madaan, "Sustainable manufacturing evaluation model focusing leather industries in India: A TISM approach," Journal of Science and Technology Policy Management, 2019.

7. S. Dixit, A. Yadav, P. D. Dwivedi and M. Das, "Toxic hazards of leather industry and technologies to combat threat: a review," Journal of Cleaner Production, Vol. 87, 2015, 39-49.

8. B. Cimatti, G. Campana and L. Carluccio, "Eco design and sustainable manufacturing in fashion: A case study in the luxury personal accessories industry," Procedia Manufacturing, Vol. 8, 2017, 393-400.
9. J. R. Rao, P. Thanikaivelan, K. J. Sreeram and B. U. Nair, "Tanning studies with basic chromium sulfate prepared using chrome shavings as a reductant: A call for'wealth from waste'approach to the tanning industry," Journal of the American Leather Chemists Association, 2004.

10. H. Ozgunay, S. Colak, M. M. Mutlu and F. Akyuz, "Characterization of Leather Industry Wastes," Polish Journal of Environmental Studies, 2007, 16(6).

11. J. Kanagaraj, K. C. Velappan, N. K. Babu and S. Sadulla, "Solid wastes generation in the leather industry and its utilization for cleaner environment-A review," 2006.

12. K. Kolomaznik, M. Adámek, I. Andel and M. Uhlirova, "Leather waste-potential threat to human health, and a new technology of its treatment," Journal of Hazardous Materials, Vol. 160(2-3), 2008, 514-520.

13. B. Ocak, "Complex coacervation of collagen hydrolysate extracted from leather solid wastes and chitosan for controlled release of lavender oil," Journal of environmental management, Vol. 100, 2012, 22-28.

14. K. Fela, K. Wieczorek-Ciurowa, M. Konopka and Z. Woźny, "Present and prospective leather industry waste disposal," Polish Journal of Chemical Technology, Vol. 13(3), 2012, 53-55.

15. W. Khan, M. E. Hossin and M. J. Akbor, "Leather Industry in Bangladesh: A Systematic Literature Review," Asian Business Review, Vol. 5(3), 2015,111-118.

16. S. C. Singh and D. Gupta, "Sustainability: A Challenge for Indian Leather Industry," Journal of Supply Chain Management Systems, Vol. 2(4), 2013.

17. N. Che Jamin and N. Z. Mahmood, "Scheduled Waste Management in Malaysia: An Overview," In Advanced Materials Research, Vol. 1113, 2015, pp. 841-846, Trans Tech Publications.

18. H. I. Abdel-Shafy and M .S. Mansour, "Solid waste issue: Sources, composition, disposal, recycling, and valorization," Egyptian journal of petroleum, 2018.

19. P. Lu, Q. Huang, A. T. Bourtsalas, N. J. Themelis, Y. Chi and J. Yan, "Review on fate of chlorine during thermal processing of solid wastes," Journal of Environmental Sciences, 2018.

20. F. Cherubini, S. Bargigli and S. Ulgiati, "Life cycle assessment (LCA) of waste management strategies: Landfilling, sorting plant and incineration,” Energy, Vol. 34(12), 2009, 2116-2123.

21. M. A. Rajaeifar, M. Tabatabaei, H. Ghanavati, B. Khoshnevisan and S. Rafiee, "Comparative life cycle assessment of different municipal solid waste management scenarios in Iran. Renewable and Sustainable,' Energy Reviews, Vol. 51, 2015, 886-898.

22. K. Govindan, D. Kannan and K. M. Shankar, "Evaluating the drivers of corporate social responsibility in the mining industry with multi-criteria approach: A multi-stakeholder perspective," Journal of cleaner production, Vol. 84, 2014, 214-232.

23. K. Śmiechowski and M. Lament, "Impact of Corporate Social Responsibility (CSR) reporting on pro-ecological actions of tanneries," Journal of Cleaner Production, Vol. 161, 2017, 991-999.

24. K. Govindan, H. Soleimani and D. Kannan, "Reverse logistics and closed-loop supply chain: A comprehensive review to explore the future," European Journal of Operational Research, Vol. 240(3), 2015, 603-626.

25. D. Jamali, P. Lund-Thomsen and N. Khara, "CSR institutionalized myths in developing countries: An imminent threat of selective decoupling," Business \& Society, Vol. 56(3), 2017, 454-486.

26. D. Jamali, P. Lund-Thomsen and S. Jeppesen, "SMEs and CSR in developing countries," Business \& Society, Vol. 56(1), 2017, 11-22.

27. P. T. Sundari and C. Vijayalakshmi, "A comprehensive review of closed loop supply chain," Glob J Pure Appl Math, Vol. 12(4), 2016, 2785-2792.

28. M. Aravendan and R. Panneerselvam, "Application of Hybrid Genetic Algorithm for CLSC Network Design Problem in Fashion Footwear Industry-A Case Study Approach," Journal of Service Science and Management, Vol. 9(03), 2016, 195.

29. A. Luca, D. S. Domene and F. A. Ais, "Life Cycle Assessment of Two Alternative End-of-Life Scenarios for Leather Safety Shoes".

30. T. Staikos and S. Rahimifard, "Post-consumer waste management issues in the footwear industry," Proceedings of the Institution of Mechanical Engineers, Part B: Journal of Engineering Manufacture, Vol. 221(2), 2007, 363-368.

31. M. Haupt, T. Kägi and S. Hellweg, "Modular life cycle ass.essment of municipal solid management," Waste waste

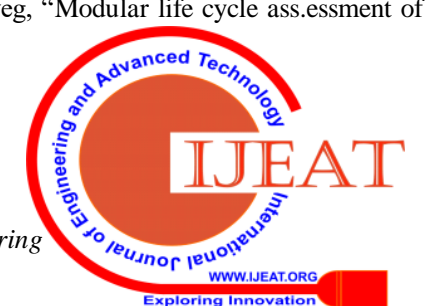




\section{Leather waste management scenario in Developed and Developing nations: A Comparative}

Management, Vol. 79, 2018, 815-827.

32. M. I. Liao, P. C. Chen, H. W. Ma and S. Nakamura, "Identification of the driving force of waste generation using a high-resolution waste input-output table," Journal of Cleaner Production, Vol. 94, 2015 294-303.

33. R. Joshi and S. Ahmed, "Status and challenges of municipal solid waste management in India: A review," Cogent Environmental Science, Vol. 2(1), 2016, 1139434

34. M. A. S. Mia, M. Nur-E-Alam, A. W. Murad, F. Ahmad and M. K. Uddin "Waste Management \& Quality Assessment of Footwear Manufacturing Industry in Bangladesh: An Innovative Approach," International Journa of Engineering and Management Research (IJEMR), Vol. 7(4), 2017, 402-407.

35. J. T. Kirkeby, H. Birgisdottir, T. L. Hansen, T. H. Christensen, G. S Bhander and M. Hauschild, "Environmental assessment of solid waste systems and technologies: EASEWASTE," Waste Management \& Research, Vol. 24(1), 2016, 3-15.

36. A. Moktadir, T. Rahman, C. J. C. Jabbour, S. m. Ali and G. Kabir, "Prioritization of drivers of corporate social responsibility in the footwear industry in an emerging economy: A fuzzy AHP approach," Journal of cleaner production, Vol. 201, 2018, 369-381.

37. B. Esmaeilian, B. Wang, K. Lewis, F. Duarte, C. Ratti and S. Behdad, "The future of waste management in smart and sustainable cities: A review and concept paper," Waste Management, Vol. 81, 2018, 177-195.

38. P.Thanikaivelan, J. R. Rao, B. U. Nair and T. Ramasami, "Recent trends in leather making: processes, problems, and pathways," Critical Reviews in Environmental Science and Technology, Vol. 35(1), 2005, 37-79.

39. J. Kanagaraj, T. Senthilvelan, R. C. Panda and S. Kavitha, "Eco-friendly waste management strategies for greener environment towards sustainable development in leather industry: a comprehensive review," Journal of Cleaner Production, Vol. 89, 2015, 1-17.

40. Z. Fang, Y. C. Yong, J. Zhang, G. Du and J. Chen, "Keratinolytic protease: a green biocatalyst for leather industry," Applied microbiology and biotechnology, Vol. 101(21), 2017, 7771-7779.

41. J. M. Morera, E. Bartoli and R. M. Gavilanes, "Hide unhairing: achieving lower pollution loads, decreased wastewater toxicity and solid waste reduction," Journal of cleaner production, Vol. 112, 2016, 3040-3047.

42. X. Dang and Z. Shan, "Dust pollution and control with leather waste," Environmental chemitry letters, Vol. 16(2), 2018, 427-437.

43. M. Sathish, B. Madhan and J. R. Rao, "Leather solid waste: An eco-benign raw material for leather chemical preparation-A circular economy example," Waste Management, Vol. 87, 2019, 357-367.

44. V. Beghetto, F. Ugolini, A. Tortora, L. Taddei, A. Scrivanti and R. Sole, "Green Biopolymers for Ecofriendly Leather," Journal of Materials Science and Engineering A, Vol. 7(7-8), 2017, 199-205.

45. D. A. Bondrea, G. Lazaroiu, R. Mocanu, A. N. Stan, L. Balanescu, L. Mihaescu and V. Berbece, "The energy method to protect the environment from waste in the leather industry," In 2017 International Conference on ENERGY and ENVIRONMENT (CIEM), 2017, pp. 105-109. IEEE.

46. R. Singh, M. Kumar, A. Mittal and P. K. Mehta, "Microbial enzymes: industrial progress in 21st century," 3 Biotech, Vol. 6(2), 2016, 174

47. B. Ravindran, S. L. Dinesh, L. J. Kennedy and G. Sekaran, "Vermicomposting of solid waste generated from leather industries using epigeic earthworm Eisenia foetida," Applied biochemistry and biotechnology, Vol. 151(2-3), 2008, 480-488.

48. J. Durga, A. Ranjithkumar, R. Ramesh, K. T. P. V. Girivasan, C. Rose, and C. Muralidharan, "Replacement of lime with carbohydrases-a successful cleaner process for leather making," Journal of cleaner production, Vol. 112, 2016, 1122-1127.

49. J. Bień, P. Celary and K. Wystalska, "The problems in achieving sustainable development in the Tannery industry in regard to sewage sludge management," Journal of Ecological Engineering, Vol. 18(6), 2017.

50. S. Kumar Gupta, S. Gupta and S. Gayathiri, "Pollution prevention is the key to drive sustainability: Preliminary findings from a tannery unit in India," Management of Environmental Quality: An International Journal, Vol. 29(3), 2018, 416-426.

\section{AUTHORS PROFILE}

K.Koppiahraj obtained his B.E (MECH) in 2014 from the Erode sengunthar engineering college, Erode, Tamilnadu, India. He completed his M.Tech (CAD/CAM) in 2016 at the B.S.Abdur Rahman Crescent institute of science and technology, Chennai, Tamilnadu, India. Currently, he is a Research Scholar in the Department of Mechanical Engineering, Kalasalingam Academy of Research and Education, Krishnankoil, Tamilnadu, India. His research interests include multi-criteria decision making and application of fuzzy set theory in real life decision problems. He is currently pursuing PHD in the area of analyzing Day-today challegnes in leather industries using MCDM techniques.

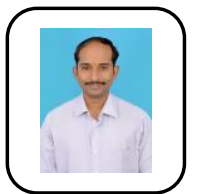

Dr.S.Bathrinath is an Associate Professor in the Department of Mechanical Engineering, Kalasalingam Academy of Research and Education, Krishnankoil, Tamilnadu, India. His current area of research includes multi-criteria decision making, scheduling \& optimization, soft computing and Artificial intelligence. He has published a number of papers in journal of national/international repute and presented a number of papers in various conferences/symposia in India and abroad. He is presently guiding a number of master/doctoral research scholars. Dr.S.Bathrinath is the corresponding author and can be contacted at: bathri@gmail.com

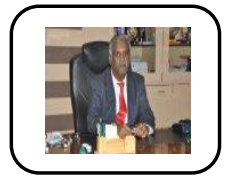

Dr.S.Saravanasankar is a Senior Professor in the Department of Mechanical Engineering, Kalasalingam Academy of Research and Education, Krishnankoil, Tamilnadu, India. He has more than 20 years of experience in teaching and research. His current area of research includes scheduling, optimization an multi-criteria decision making. He has published more than 40 research articles in journals of national and international repute. 